\title{
STUDIES ON CONSORTIUM OF MARINE OIL DEGRADING BACTERIA FOR DEGRADATION OF HIGH SPEED DIESEL (HSD)
}

\author{
Namrata Kamble ${ }^{1 *}$, Chitra Pawar ${ }^{1}$, Rajamani Mohanram ${ }^{1}$ and Susan Titus ${ }^{1}$ \\ Marine Biotechnology Department, Naval Materials Research Laboratory, Defence Research and \\ Development Organisation, Ambernath (East), Mumbai 421 506, India.
}

\begin{abstract}
Three bacterial strains namely RM1, RM2 and RM3 were isolated from oil polluted site of Mumbai harbor and were explored for growth on HSD as sole source of carbon and energy in four different combinations. Parameters investigated were growth of bacteria by optical density measurement along with viable count, production of bio-surfactant/ bio-emulsifier, its biochemical characterization and percent degradation of diesel by gravimetric method. Consortium A consisting of RM1 and RM2 degraded 52.56\% of HSD $(4 \% \mathrm{v} / \mathrm{v})$ in 7 days employing $2 \%(\mathrm{v} / \mathrm{v})$ of bacterial inoculum at room temperature on rotary shaker. Surface Tension of the Cell Free Filtrate (CFF) dropped from $68 \mathrm{mN} / \mathrm{mto}<43 \mathrm{mN} / \mathrm{m}$ in all the cases indicating the ability of bacteria to produce extracellular surface active agents. The Emulsification Activity $\left(\mathrm{EA}_{24}\right)$ of CFF prepared from culture broth of Consortium $\mathrm{C}$ and $\mathrm{D}$ was $100 \%$ with $\mathrm{C}_{8}-\mathrm{C}_{19}$ hydrocarbons whereas Consortium A exhibited $75-100 \% \mathrm{EA}_{24}$ with alkanes ranging from carbon number $\mathrm{C}_{10}-\mathrm{C}_{19}$. Results revealed that the oil degrading bacteria of consortia taken in this study hadthe potential to degrade hydrocarbons and could be further employed for remediation of HSD spillage.
\end{abstract}

\author{
Keywords \\ Biodegradation \\ Consortium \\ High Speed Diesel \\ Biosurfactant \\ Bioemulsifier \\ Emulsification Activity \\ Surface Tension
}

\section{Introduction}

Natural resources of oil are being exploited for fulfilling the energy demands of today's world. The dependency on transportation from one port to the other for supply increases along with the increase in demand $(1,2)$. In view of this, oil spills caused by accidental or anthropogenic activities in the sea causes great harm to the environment. The oil is either swept to farther areas, covers the surface or gets into the sediments after long run. It blocks adequate sunlight and also reduces the dissolution of oxygen, thus limiting the survival of natural flora and fauna in the aquatic ecosystem (3).

Several physico-chemical methods are used in response to oil spills. Physical methods involve use of barriers, booms, skimmers and absorbent materials to remove the overlaying surface oil. However, they barely succeed in complete removal of oil. Chemical methods involve the use of solvents or mixture of synthetic surfactants that breaks the oil into droplets. These droplets enter the water column and impart stress on the living inhabitants. These methods partially remove the oil from the environment and the persisting hydrocarbon (HC) \& its components possess risk to the environment $(2,4)$. Although some of the oil contaminants are broken by photo-oxidation and evaporation, complete elimination depends on the metabolic activities of microbial population $(5,6)$.

Bioremediation is an eco-friendly strategy to deal with this menace. The ability of the bacteria to utilize the HCs has been documented since 1940s. This technology has been used to remediate marine oil spill since 1970 s $(3,7)$. But the degradation capability varies with the change in chemical structure of the compound (8). This method is environmentfriendly, low in cost, non-toxic and does not generate secondary pollution while the other methods are laborintensive and usually expensive $(7,9,10)$. 
Biodegradation is the breakdown of complex substances into simpler ones brought about by cellular enzymes. This brings about significant changes in the chemical structure of the organic pollutant resulting in the production of carbon dioxide, water and new microbial cellular constituents (biomass). The aerobic pathway leads to conversion of alkane chains into fatty acids, alcohol, aldehyde and carboxylic acids which are then channeled into the central metabolic process for $\beta$-oxidation. Single bacterium may not possess all the necessary biodegradative enzymes for breakdown of pollutants. Mixed microbial community acquire an array of catabolic genes and the cumulative effect of these gene products help in the degradation of complicated mixture of organic compounds present in the contaminated sites (11).

Hydrocarbons are insoluble in water; its solubility can be increased with the help of surface active agents (SAAs). Marine bacteria release Bio-surfactant (BS)/ Bio- emulsifier (BE) which facilitates the uptake of water- insoluble substrates present in the environment. BSs are amphipathic in nature comprising of hydrophilic and hydrophobic domains. The formation of micro-emulsions with the creation of micelle helps in solubilization of $\mathrm{HC}$ in water. This helps in reduction of Surface Tension (ST) of the system and allows the overlaying immiscible liquid to penetrate into water column (12).

Diesel oil is made up of n-alkanes (42.7\%), cycloalkanes (33.4\%) and aromatic (23.9\%) HCs. Aliphatic HCs ranging from $\mathrm{C}_{9}$ to $\mathrm{C}_{23}$ constitutes the major part. The utilization of such complex oil is shared by diverse microbial community. Some bacteria remain specialized in using a single type of substrate while some are capable of using a group of compounds $(8,13)$.

In an open sea, bioremediation is much more challenging due to constant fluctuating environmental conditions like tidal actions, changing seasons and transportation activities (6). Therefore, use of more than one bacterium will prove to be advantageous at the site of interest.

Over the years, studies on degradation of crude oil by bacteria have been reported throughout the world. But study on degradation of HSD by native bacterial consortia is limited (9). With relation to this, the present study focuses on testing combinations of marine oil degrading bacterial isolates from Mumbai harbor for its growth and utilization of HSD. It also aims on understanding the ability of bacterial strains for production of surface active agents for enhancing the bioavailability of insoluble HSD by bacteria.

\section{Materials And Methods}

\section{Bacterial consortia}

Bacterial strains were isolated from oil polluted site of Mumbai harbor. Isolation of oil degrading bacteria was carried out by enrichment technique (14). The three isolates were named as RM1, RM2 and RM3. Different combinations of three oil degrading bacteria were made as given below and used for this study (Table 1).

Table 1: Composition of bacterial consortia.

\begin{tabular}{|c|c|}
\hline Consortium Name & Bacteria present \\
\hline A & RM1 + RM2 \\
\hline B & RM2 + RM3 \\
\hline C & RM1 + RM3 \\
\hline D & RM $1+R M 2+R M 3$ \\
\hline
\end{tabular}

\section{Media preparation and inoculation}

HSD was obtained from Naval Dockyard, Mumbai. The three bacterial strains were grown separately on Zobell Marine Agar (ZMA) plates. Single colony of bacteria was then inoculated into $100 \mathrm{ml}$ conical flask containing $50 \mathrm{ml}$ of sterile Modified Bushnell Haas Broth (MBHB) with 1\% HSD (filtered through $0.22 \mu \mathrm{m}$ membrane filter) and incubated at $37^{\circ} \mathrm{C}$ on a shaker incubator (Murhopye Scientific, India) at $180 \mathrm{rpm}$ for $24 \mathrm{hrs}$.Optical Density (OD) of the culture medium was measured at $600 \mathrm{~nm}$ using US-Vis Spectrophotometer (Labtek, India) (15). OD of culture suspension measuring 0.5 was used as inoculum. Aliquots of each culture suspension were added to give $2 \%$ (v/v) of mixed bacterial consortia into $250 \mathrm{ml}$ conical flask containing $100 \mathrm{ml}$ of sterile MBHB supplemented with $4 \%$ $(v / v)$ HSD. The flasks were then incubated on a rotary shaker (Scigenics Biotech, India) at $180 \mathrm{rpm}$ at room temperature (RT). The experimental flasks were removed after $3^{\text {rd }}, 5^{\text {th }}$ and $7^{\text {th }}$ day ofincubation (each in triplicate along with control). Parameters to be studied were then carried out.

\section{Viable count}

The viable count of the cultures was determined by Spread plate technique. Serial dilution set was prepared using $0.89 \%$ of sterile saline in sterile $1.5 \mathrm{ml}$ tubes. In $900 \mu \mathrm{l}$ of saline, 100 $\mu l$ of culture suspension was added and vortexed. From this $100 \mu \mathrm{l}$ of aliquot was plated on sterile ZMA from respective dilution tube. The plates were incubated at $37^{\circ} \mathrm{C}$ for $24 \mathrm{hrs}$. After incubation, the number of colonies were counted and using the below formula viable counts were found out.

Viable count $(\mathrm{CFU} / \mathrm{ml})=$ Number of colonies/ Volume of sample taken for plating in $\mathrm{mL}^{*}$ Dilution factor

\section{Gravimetric analysis}

The weight of initial oil added (4ml) was $3.331 \mathrm{gm}$. After termination on respective days, the broth was centrifuged at $15,000 \mathrm{rpm}$ at $4^{\circ} \mathrm{C}$ for $20 \mathrm{mins}$ and the upper layer of oil was collected into pre-weighed container. The percent degradation was found using the below formula:

$\%$ of oil degradation= Weight of remaining oil - Weight of initial oil added/ Weight of initial oil*100 


\section{pH change}

The $\mathrm{pH}$ of the culture supernatant was measured using $\mathrm{pH}$ meter (Thermo Scientific, USA) after termination of growth.

\section{Surface Tension measurement}

The surface tension was determined by Wilhelmy plate method (16). The culture supernatant was filtered using $0.22 \mu \mathrm{m}$ membrane filter to remove any remnant cells from it to obtain a CFF. $10 \mathrm{ml}$ of CFF was taken from each flask in automated Surface Tensiometer (Kyowa, Japan). Sterile MBHB was used as Blank.

\section{Emulsification Activity}

$\mathrm{EA}_{24}$ was determined by mixing $6 \mathrm{ml}$ of $\mathrm{CFF}$ with $0.6 \mathrm{ml}$ of HSD and vortex at high speed for 2 mins. The tubes were kept standing and the readings were taken after $24 \mathrm{hrs}$ (17). EA 24 was calculated using the below formula:

$\mathrm{EA}_{24}(\%)=$ Height of emulsified layer/ Height of Total layer*100 (Total layer= Height of Oil phase+ Emulsified phase)

\section{Biochemical analysis}

Folin-Lowry and Dubois methods were used to determine the protein and carbohydrate content of the CFFs respectively $(18,19)$.

\section{Results}

Viable count \& Optical Density

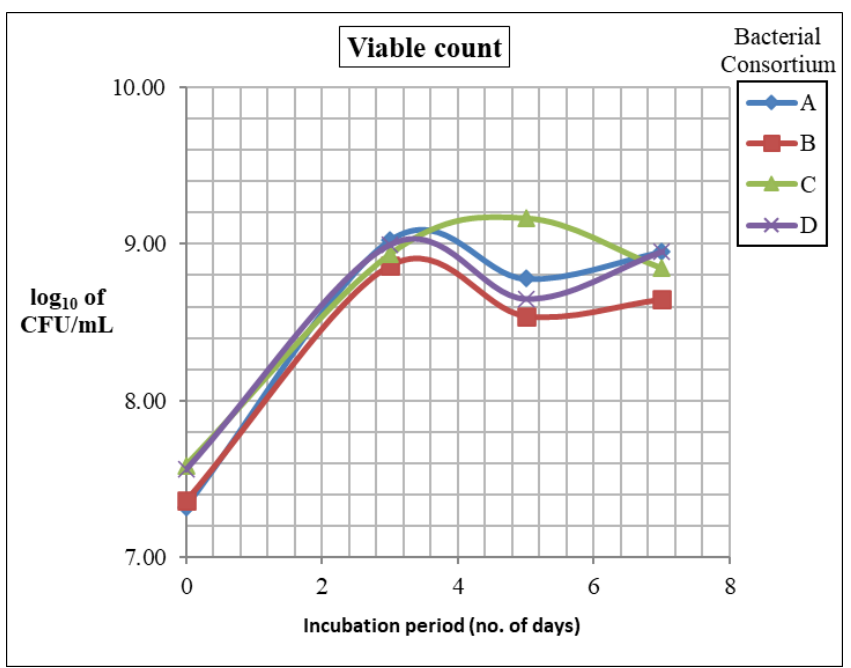

Figure 1: Graphical representation of viable count vs. incubation period.

The culture was pre-grown in HSD to obtain actively growing bacteria to avoid prolonged lag-phase (15). Culture suspensions of $0.5 \mathrm{OD}$ corresponding to $15 \times 10^{5}, 13.65 \times 10^{5}$ and $26.86 \mathrm{X} 10^{5} \mathrm{CFU} / \mathrm{ml}$ of RM1, RM2 and RM3 respectively, were taken to inoculate the flasks.

After 3 days of incubation viable count for consortia A, B and $\mathrm{D}$ exhibited growth of $11.5 \times 10^{8}, 7.77 \times 10^{8}$ and $9.9 \mathrm{X}$
Folin-Lowry method: Bovine Serum Albumin (BSA) (Sigma Aldrich, USA) was used as Standard. $1 \mathrm{mg} / \mathrm{ml}$ of BSA was prepared in distilled water and used as working stock. Standard graph was plotted using concentration of BSA (ranging from $25-300 \mu \mathrm{g} / \mathrm{ml}$ ) vs. absorbance.

$5 \mathrm{ml}$ of alkaline solution was added in a test tube with $1 \mathrm{ml}$ of CFF. It was kept at RT for 10 mins. In this tube, $0.5 \mathrm{ml}$ of $1 \mathrm{~N}$ Folin-Ciocalteau's phenol reagent (Sigma Aldrich, USA) was added, mixed and kept at RT for 30mins. Then OD was taken at 750nm using UV-Visible Spectrophotometer (Lab India analytical, India).

Dubois method: D-glucose was used as Standard. $1 \mathrm{mg} / \mathrm{ml}$ of D-glucose was prepared in distilled water and used as working stock. Standard graph was created using concentration of D-glucose (ranging from $25-300 \mu \mathrm{g} / \mathrm{ml}$ ) vs. absorbance.

In a test tube, $1 \mathrm{ml}$ of CFF was added with $1 \mathrm{ml}$ of $5 \%$ phenol (Sigma Aldrich, USA) and vortexed. 5ml of concentrated Sulphuric acid was added to this and kept at RT for 10mins. Then OD was measured at 490nm using UV-Visible Spectrophotometer (Lab India analytical, India).

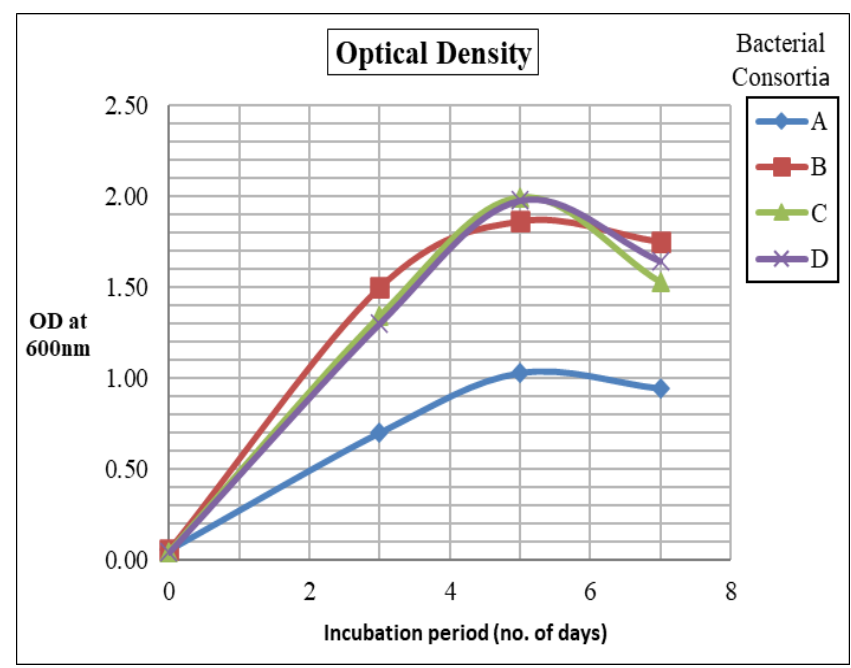

Figure 2: Graphical representation of OD vs. incubation period.

$10^{8} \mathrm{CFU} / \mathrm{ml}$, however consortia $\mathrm{C}$ exhibited further growth and a count of $14.8 \times 10^{8} \mathrm{CFU} / \mathrm{ml}$ was obtained after 5days of incubation. The viable count in all cases was found to remain more or less constant after this period (Figure 1).

OD of the culture medium was also determined at $600 \mathrm{~nm}$ to monitor the growth of bacterial cells $(9,20,21,22)$. It was found that the OD of consortia reached maximum (1.03, 1.86, 
2.0 and 1.98 for consortia $\mathrm{A}, \mathrm{B}, \mathrm{C}$ and $\mathrm{D}$ respectively) after 5 days of incubation. A common trend of increase in OD till 5 days of incubation was seen after which it reduced (Figure 2).

\section{Gravimetric analysis}

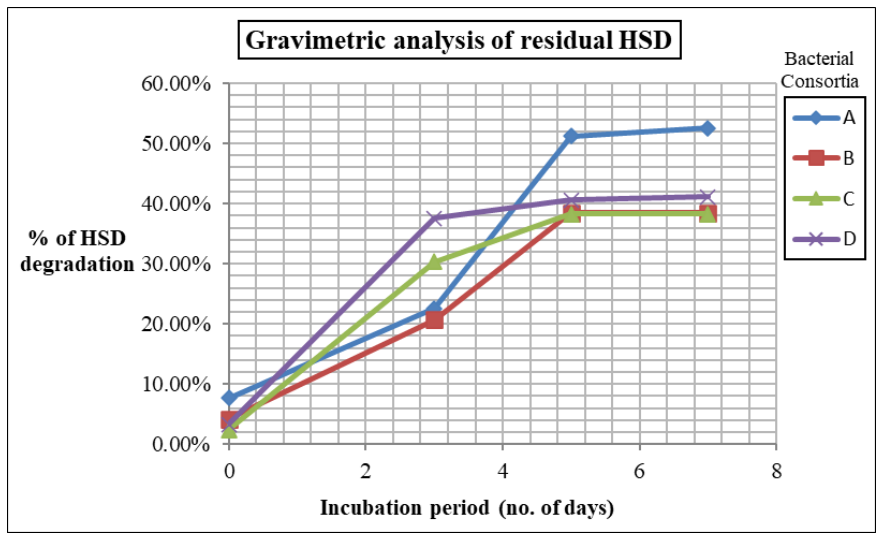

Figure 3: Graphical representation of percentage of HSD degradation.

Utilization of diesel oil was found to be more during the exponential phase of growth. It was seen that the bacteria in each combination was able to utilize and degrade HSD. After 5 days of incubation the bacteria in Consortium A, B, C \& D degraded $52.56 \%, 38.46 \%, 38.31 \%$ \& $43.07 \%$ of diesel oil respectively (Figure 3 ).

\section{pH change}

Table 2: Change in $\mathrm{pH}$ of broth of bacterial consortia.

\begin{tabular}{|c|c|c|c|}
\hline \multirow{2}{*}{ Consortia } & \multicolumn{3}{|c|}{$\mathbf{p H}$} \\
\cline { 2 - 4 } & \multicolumn{3}{|c|}{ Incubation period (no. of days) } \\
\cline { 2 - 4 } & $\mathbf{3}$ & $\mathbf{5}$ & $\mathbf{7}$ \\
\hline CONTROL & $7.295 \pm 0.01$ & $7.23 \pm 0.0$ & $7.13 \pm 0.3$ \\
\hline A & $7.7 \pm 0.02$ & $8.08 \pm 0.08$ & $8.20 \pm 0.05$ \\
\hline B & $7.6 \pm 0.03$ & $8.08 \pm 0.09$ & $8.00 \pm 0.06$ \\
\hline C & $7.44 \pm 0.01$ & $8.08 \pm 0.06$ & $7.95 \pm 0.14$ \\
\hline D & $7.6 \pm 0.06$ & $8.08 \pm 0.08$ & $7.97 \pm 0.07$ \\
\hline
\end{tabular}

Average $\pm \mathrm{SD}, \mathrm{n}=3$

The initial $\mathrm{pH}$ of the broth was set at $7.5 \pm 0.2$. The $\mathrm{pH}$ of culture broth increased slightly and turned alkaline for all the combinations as compared to control flasks of respective days (Table 2).

\section{Surface Tension}

Table 3: Surface Tension of CFF of bacterial consortia.

\begin{tabular}{|c|c|c|c|}
\hline \multirow{2}{*}{$\begin{array}{l}\text { ST of CFF } \\
(\mathrm{mN} / \mathrm{m})\end{array}$} & \multicolumn{3}{|c|}{ Incubation period (no. of days) } \\
\cline { 2 - 4 } & $\mathbf{3}$ & $\mathbf{5}$ & $\mathbf{7}$ \\
\hline A & $40.20 \pm 3.25$ & $42.32 \pm 1.13$ & $38.83 \pm 1.27$ \\
\hline B & $42.37 \pm 2.25$ & $40.84 \pm 0.63$ & $41.99 \pm 1.65$ \\
\hline C & $40.63 \pm 3.80$ & $37.03 \pm 0.73$ & $39.06 \pm 0.93$ \\
\hline D & $40.82 \pm 1.88$ & $38.64 \pm 2.62$ & $43.07 \pm 0.84$ \\
\hline
\end{tabular}

Average $\pm \mathrm{SD}, \mathrm{n}=6$

The surface tension reduction measurement of the CFF was recorded as a measure for release of SAA in the growth medium. For all the bacterial combinations the ST reduced from $68 \mathrm{mN} / \mathrm{m}$ (Blank) to $<43 \mathrm{mN} / \mathrm{m}$ in (Table 3 ).

\section{Emulsification activity (EA24) with different hydrocarbons}

Table 4: Emulsification Activity of CFF of bacterial consortia.

\begin{tabular}{|l|c|c|c|c|}
\hline \multirow{2}{*}{$\begin{array}{l}\text { Hydro- } \\
\text { carbon } \\
\text { used }\end{array}$} & \multicolumn{4}{|c|}{$\mathrm{EA}_{24}$ (\%) by bacterial consortia } \\
\cline { 2 - 5 } & $\mathbf{A}$ & B & C & D \\
\hline $\begin{array}{l}\text { C8-0ctane } \\
\text { C9-Nonane }\end{array}$ & $33.33 \pm 3.0$ & $66.66 \pm 4.52$ & $100.00 \pm 2.4$ & $100.00 \pm 2.6$ \\
\hline C10-n-Decane & $100.00 \pm 2.21$ & $33.33 \pm 1.25$ & $100.00 \pm 3.3$ & $100.00 \pm 2.31$ \\
\hline C12-Dodecane & $100.00 \pm 1.8$ & $33.33 \pm 1.72$ & $100.00 \pm 4.2$ & $100.00 \pm 3.0$ \\
\hline C14-Tetradecane & $100.00 \pm 1.45$ & $66.66 \pm 2.69$ & $100.00 \pm 2.63$ & $100.00 \pm 2.8$ \\
\hline $\begin{array}{l}\text { C16- n- } \\
\text { Hexadecane }\end{array}$ & $75.00 \pm 2.63$ & $25.00 \pm 2.48$ & $100.00 \pm 2.47$ & $100.00 \pm 3.32$ \\
\hline C19- Pristane & $100.00 \pm 3.65$ & $73.33 \pm 4.2$ & $100.00 \pm 1.8$ & $100.00 \pm 3.5$ \\
\hline
\end{tabular}

Average $\pm \mathrm{SD}, \mathrm{n}=3$

Formation of emulsion between hydrophobic substrates and culture supernatant was tested. Medium containing SAA produced by bacteria helps in penetration of oil molecules into the water layer. This enhances the availability of oil for uptake by bacterial cells. $\mathrm{EA}_{24}$ determines the percentage of emulsion formation capacity and its stability, which was monitored till $24 \mathrm{hrs}$.

The $\mathrm{EA}_{24}$ of CFF of Consortium $\mathrm{C}$ and $\mathrm{D}$ was $100 \%$ with carbon number alkanes ranging from $\mathrm{C}_{8}-\mathrm{C}_{19}$. Consortium $\mathrm{B}$ showed moderate EA(33-75\%) with wide range of HCs. Consortium A did not exhibit good emulsion stability with short chain alkanes $\left(\mathrm{C}_{8}-\mathrm{C}_{9}\right)$ however with medium and high carbon number alkanes $\left(\mathrm{C}_{10}-\mathrm{C}_{19}\right)$ it was found to be stable (Table 4). 


\section{Biochemical analysis}

\section{Protein estimation}

Table 5: Concentration of Protein in CFF of bacterial consortia.

\begin{tabular}{|c|c|c|c|c|}
\hline \multirow{2}{*}{$\begin{array}{c}\text { Incubation } \\
\text { period (no. of days) }\end{array}$} & \multicolumn{4}{|c|}{ Concentration of protein $(\boldsymbol{\mu g} / \mathbf{m l})$} \\
\cline { 2 - 5 } & A & B & C & D \\
\hline 3 & $97.42 \pm 3.79$ & $138.68 \pm 2.18$ & $114.97 \pm 2.18$ & $127.35 \pm 6.7$ \\
\hline 5 & $332.82 \pm 12.23$ & $404.56 \pm 6.52$ & $408.47 \pm 11.22$ & $387.74 \pm 9.64$ \\
\hline 7 & $344.15 \pm 3.16$ & $312.00 \pm 6.59$ & $328.70 \pm 4.58$ & $293.58 \pm 2.79$ \\
\hline
\end{tabular}

Average $\pm \mathrm{SD}, \mathrm{n}=3$

The CFF obtained from all combinations was examined for its protein and carbohydrate content by spectrophotometric method. Determination of biochemical content will help in understanding the nature of secreted metabolites. It was seen that in all the cases the protein concentration increased after
3 days of incubation and thereafter after 5 days it reduced slightly. For consortium A, protein concentration was $344.15 \mu \mathrm{g} / \mathrm{ml}$ after 7 days of incubation. For consortia B and C protein concentration was 408.47 \& $387.74 \mu \mathrm{g} / \mathrm{ml}$ respectively after 5 days of incubation period (Table 5).

\section{Carbohydrate estimation}

Table 6: Concentration of Carbohydrate in CFF of bacterial consortia.

\begin{tabular}{|c|c|c|c|c|}
\hline \multirow{2}{*}{$\begin{array}{c}\text { Incubation } \\
\text { period (no. of days) }\end{array}$} & \multicolumn{4}{|c|}{ Concentration of carbohydrate $(\boldsymbol{\mu g} / \mathrm{ml})$} \\
\cline { 2 - 5 } & $\mathrm{A}$ & $\mathrm{B}$ & $\mathrm{C}$ & $\mathrm{D}$ \\
\hline 3 & $62.81 \pm 3.26$ & $32.64 \pm 2.51$ & $45.50 \pm 1.15$ & $57.94 \pm 3.2$ \\
\hline 5 & $80.15 \pm 0.83$ & $38.84 \pm 0.37$ & $39.91 \pm 2.90$ & $49.10 \pm 1.28$ \\
\hline 7 & $49.31 \pm 3.45$ & $55.66 \pm 5.18$ & $62.97 \pm 1.02$ & $51.08 \pm 2.41$ \\
\hline
\end{tabular}

Average $\pm \mathrm{SD}, \mathrm{n}=3$

The concentration of carbohydrate in CFF was determined and found to be less than the protein content in all combinations of bacteria. For Consortium B and C, carbohydrate content was $50-60 \mu \mathrm{g} / \mathrm{ml}$ after 7 days of incubation, while for Consortium A it was $\sim 80 \mu \mathrm{g} / \mathrm{ml}$ after 5 days of incubation (Table 6).

\section{Discussion}

The indigenous microorganisms inhabiting petroleum oil polluted marine environment are crucial for natural attenuation of hydrocarbons (HCs) during an oil spill. Oil degrading bacteria produce surface active agents which emulsify oil with water, resulting in increased bioavailability of these oil droplets for uptake and subsequent utilization by bacteria for biodegradation (23).

Reported oil biodegradation studies revealed an initial increase in number of bacterial cells in response to sudden surplus in carbon levels (24). Increase in number of bacterial cells indicates survival of the introduced consortia in the presence of HCs (25). In our study also, the count of bacteria increased and indicated the ability of bacteria to gr ow in the presence of HSD. During the exponential phase of growth, the bacterial cells utilized diesel oil for reproduction and synthesis of cellular components. After the exponential phase, the bacterial load remained more or less similar. In agreement with our results, a study reported initial count of bacteria ranged from $10^{4}-10^{5} \mathrm{CFU} / \mathrm{ml}$ and then hiked to $2 \mathrm{X} 10^{6}$ and $10^{7} \mathrm{CFU} / \mathrm{ml}$ in 10days of incubation period. The population remained fairly stable for rest of the study (24). Similarly, in another study performed with consortia on spent engine oil $(1 \% \mathrm{v} / \mathrm{v})$ gradual increase in viability was also observed only till 15days (4).

Turbidity of the growth medium was also measured in terms of OD to detect increase in cell numbers. The increase in OD indicated the knack of bacteria to grow in the presence of diesel oil by secreting requisite enzymes for its metabolism. It was able to utilize diesel as a sole source of carbon and energy. This may be due to increased bioavailability of the 
$\mathrm{HC}$ to the bacterial cells. In a study, the OD reached $1.78 \pm 0.2$ for consortia cultivated in $1 \%(\mathrm{v} / \mathrm{v})$ of crude oil at $30^{\circ} \mathrm{C}$ after 7 days of incubation. In the same study the OD of consortia was higher than that of individual strains (26). Increase in culture OD was reported till 5weeks after which it declined (9). In the present study, the viable count was maximum after 3 days of incubation whereas maximum OD was obtained after 5days of incubation. Between day 3 and 5, the increase in OD might be due to the release of extracellular products into the medium and might be the reason for enhanced turbidity despite not much increase in viable count.

In this study, biodegradation percentage determination by gravimetric analysis revealed $52.56 \%$ diesel oil degradation by Consortium A within 7days of incubation period at RT. Diesel oil is composed of mainly saturated HCs having medium length chains (27). Therefore, these bacteria were considered to possess the ability of degrading medium length chains. In a similar study, seawater bioremediation trial reported more than $50 \%$ of degradation of Hcs components by consortium but within 30days of incubation period (6). The rate of diesel oil degradation was $82.65 \%$ after 12 days of incubation with the help of both petroleum degrading bacteria as well as biosurfactant producing bacteria isolated from sea water (28).

Change in $\mathrm{pH}$ is known to affect growth of bacteria as well as the formation of emulsion. The emulsion creation capacity is seen to be lost at $\mathrm{pH}$ beyond 11 (28). $\mathrm{pH} 7$ was optimized for maximum crude oil degradation and growth of bacteria (1). In this study, the CFF of the all four consortium combinations showed a slight increase in $\mathrm{pH}$ which may be due to the alkaline chemical nature of the SAA or secondary metabolites or by-products of the catabolic reactions. Release of by- products from degradation of sludge oil post treatment with bacterial consortium for a period of 56days has been reported (30).

Surface Tension reduction value of CFF of all the four combinations of bacteria after 3 days of incubation was below $43 \mathrm{mN} / \mathrm{m}$ and reached till $37 \mathrm{mN} / \mathrm{m}$, this confirmed the production of SAA into the medium by the bacteria. A good

BS producer reduces ST of medium by $\geq 20 \mathrm{mN} / \mathrm{m}$ units as compared to distilled water (17). In present study, the ST of the culture medium reduced by $>29 \mathrm{mN} / \mathrm{m}$ units. This indicated good BS production capability of the bacteria used in this study. Reduction in ST of culture medium from 51.45 to $29.5 \mathrm{mN} / \mathrm{m}$ was achieved by bacterial consortium on degradation of crude oil after 3 weeks of incubation (9). TERIK consortium showed drop in ST from $70 \mathrm{mN} / \mathrm{m}$ to $34 \mathrm{mN} / \mathrm{m}$ in 10days (31). In another study, mixed bacterial consortium was found to exhibit excellent growth on $1 \%$ Bombay High crude oil and was able to reduce the ST from $68 \mathrm{mN} / \mathrm{m}$ to $34.1 \mathrm{mN} / \mathrm{m}$ within $84 \mathrm{hrs}(32)$.In comparison with the reported studies, the percentage of $\mathrm{HC}$ used in our study was more (4\%) and ST reduction was >25units as compared with control.
The presence of BS is necessary for production of emulsion between two immiscible liquids. If no surfactant is present, the two layers will separate after vigorous shaking. In the present study the emulsion was stable and did not separate. The $\mathrm{EA}_{24}$ determined using different $\mathrm{HCs}$ in our study revealed the presence of extracellular surface active agents. EA ranged from $40-90 \%$ with different oils used with mixed bacterial consortium culture incubated for 70 days (33). In a study, consortium showed EA of $5 \pm 1 \%$ with diesel oil (32). In the presence of $\mathrm{HCs}$, the bacteria tend to secrete some biochemical molecules to emulsify the insoluble substrate and facilitate its transportation into the cell (32). In our study, reduction in ST may be attributed by extracellular material which comprised of more of proteins as compared to carbohydrates.

To accelerate the process of bioremediation treatment of oil contaminated site it is advantageous to use a mix of bacteria rather than using a single type of bacterium wherein the metabolic capacities of individual bacterium may result in synergistic action for degradation of fuel components $(8,32$, $34,35)$. It was also reported that effect of mixed bacterial population on crude oil degradation was better as compared to individual bacteria (26). Degradation of spent engine oil $(1 \% \mathrm{v} / \mathrm{v})$ was maximum $(52 \%)$ as compared to individual bacterial strains after 10days of incubation under optimized conditions (4). Use of mixed culture over a pure culture imparts a benefit of displaying a collaborative influence between the bacterial cultures. One species may help in elimination of a toxic metabolite which might hinder the activity of other species. One may be able to degrade a compound partially then the other bacteria will degrade this partial product into a harmless end product (10). Crude oil has a complex composition. Degradation of this complex oil by bacterial consortium has been reported in several studies. A study reported $70 \%$ of crude oil degradation by bacterial consortium isolated from different contaminated sites of Aqaba region (Jordan) after 77days of incubation (36). High degradation rate of crude oil ( $1 \% \mathrm{v} / \mathrm{v})$ was accomplished with the use of consortium than with the use of single bacterium for a period of 7days (26). In a study, a consortium comprising of five bacterial strains degraded $75.1 \%$ of crude oil $(1 \% \mathrm{w} / \mathrm{v})$ in 7 days in marine environment. In the same study, 40-72\% of crude oil degradation was achieved with consortium having three strains in different volumes. Not all the consortium of bacteria displayed good bioremediation action and the oil degradation rate was lower as compared to the single ones. Competition among bacteria of a consortium could be a cause for decreased bioremediation efficiency (7). However, in our study all the four combinations efficiently utilized diesel oil.

Use of carrier agents or immobilization technique; or addition of external nutrients is emphasized to enhance the degradation capability of bacteria. Bacterial consortium mounted on shell carrier along with nutrients showed $53.3 \%$ of total petroleum hydrocarbon degradation within 27 weeks (2). Unlike in our study no such carrier agents or nutrients were used. 
In open sea, bioremediation is much more challenging due to constant fluctuating environmental conditions like tidal action, variation in temperature, changing seasons and transport activities (6). Therefore, use of more than one bacterium may prove to be beneficial at the site of remediation.

\section{Conclusion}

This study investigated the performance of three oil degrading marine bacteria on degradation of high speed diesel. Various combinations of these bacteria taken for the study were found to utilize diesel as the sole source of carbon and energy and also produced extracellular surface active agents for facilitating the uptake of insoluble substrate.

\section{References}

1. Muthuswamy Sathishkumar, Arthur Raj Binupriya, Sang-Ho Baik \& Sei-Eok Yun. Biodegradation of crude oil by individual bacterial strains and a mixed bacterial consortium isolated from hydrocarbon contaminated areas. 2008. Clean, 36(1): 92-96.

2. Petra J. Sheppard, Keryn L. Simons, Eric M. Adetutu, Krishna K. Kadali, Albert L. Juhasz, Mike Manefielz, Priyangshu M Sarma, Banwari Lal \& Andrew S. Ball. The application of a carrier-based bioremediation strategy for marine oil spills. 2014. Marine Pollution Bulletin, Vol 84(1-2): 339-346.

3. Antonio Dell'Anno, Francesca Beolchini, Laura Rocchetti, Gian Marco Luna \& Roberto Danovaro. High bacterial biodiversity increases degradation performance of hydrocarbons during bioremediation of contaminated harbor marine sediments. 2012. Environmental Pollution, Vol. 167: 85-92.

4. Ganeshkumar, Vijayakumar L, Joshi G, Magesh Peter D, Dharani G \& Kirubagaran R. Biodegradation of complex hydrocarbons in spent engine oil by novel bacterial consortium isolated from deep sea sediment. 2014.Bioresource Technology, Vol 170: 556-564.

5. Abdualdaim Mohammed Mukred, AidilAbd Hamid, AinonHamzah, Wan Mohtar\& Wan Yusoff. Development of three bacteria consortium for the bioremediation of crude petroleum-oil in contaminated water. 2008. Online Journal of Biological Sciences, 8(4): 73-79.

6. Sharon N. Nuñal, Sheila Mae S. Santander-De Leon, Eugene Bacolod, Jiro Koyama, Seiichi Uno,M a s a y s u H id a ka, Tak es hi Yosh i k a wa \&HirotoMaed. Bioremediation of heavily oil-polluted seawater by a bacterial consortium immobilized in cocopeat and rice hull powder. 2014. Biocontrol Science, Vol. 19(1): 11-22.

7. Qingguo Chen, Jingjing Li, Mei Liu, Huiling Sun \& Mutai Bao. Study on the biodegradation of crude oil by free and immobilized bacterial consortium in marine environment.2017.PLOS ONE. https://doi.org/10.1371/journal.pone.0174445.
8. Lena Ciric, James C. Philp \& Andrew S. Whiteley. Hydrocarbon utilization within a diesel-degrading bacterial consortium. 2010. FEMS Microbiol Lett, 303: 116-122.

9. Kaustuvmani Patowary, Rupshikha Patowary, Mohan C. Kalita \& Suresh Deka. Development of an efficient bacterial consortium for the potential remediation of hydrocarbons from contaminated sites. 2016. Frontiers in Microbiology, Vol 7, Article 1092.

10. Abu Baker Salleh, Farinazleen Mohamad Ghazali, Raja Noor Zaliha Abd Rahman \& Mahiran Basri. Bioremediation of petroleum hydrocarbon pollution. 2008. Indian Journal of Biotechnology. 2: 411-425.

11. Houghton J E \& Shanley M S. 1994. Chapter 1 Catabolic potential of Pseudomonads: a regulatory perspective. Biological Degradation and Bioremediation of Toxic Chemicals. G. R. Chaudhry. Dioscorides Press: Portland, Oregon. 11-32.

12. $\mathbf{N}$ Qiao and $\mathbf{Z}$ Shao. Isolation and characterization of a novel biosurafactant produced by hydrocarbondegrading bacterium AlcanivoraxdieseloleiB-5. 2009. Journal of Applied Microbiology, 108: 1207-1216.

13. Yoon-Suk Kang \& Woojun Park. Protection against diesel oil toxicity by sodium chloride-induced exopolysaccharides in Acinetobacter sp. strain DR1. 2009. Journal of Bioscience and Bioengineering. Vol. 109 (2): $118-123$.

14. Rajamani Mohanram, Chandrakant Jagtap \& Pradeep Kumar. Diversity among surface active agent producing marine oil degrading bacteria of Mumbai harbor. 2016. Marine pollution Bulletin. 105(1): 131138 .

15. S Mnif, M Chamkha \& S Sayadi. Isolation and characterization of Halomonassp. strain C2SS100, a hydrocarbon-degradaing bacterium under hypersaline conditions. 2009. Journal of Applied Microbiology, 107: 785-794.

16. Thivaharan Varadavenkatesan and Vytla Ramachandra Murty. Production of a lipopeptidebio surfactant by a novel Bacillus sp. and its applicability to enhanced oil recovery. 2013. ISRN Microbiology, Article ID 621519, 8 pages.

17. Pia A. Willumsen \& Ulrich Karlson. Screening of bacteria, isolated from PAH-contaminated soils, for production of biosurfactants and bioemulsifiers. 1997. Biodegradation.7: 415-423.

18. Lowry O H, Rosebrough J, Farr A L \& Randall R J. Protein measurement with the Folin phenol reagent. 1951. Journal of Biological Chemistry. 193: 265-275.

19. Dubois M. Colorimetric method for determination of sugar and related substance. 1956. Anal. Chem, 28(3): 350-356.

20. Majid Zeinali, Manouchehr Vossoughi, Sussan K. Ardestani, Esmaeil Babanezhad and Mohamadreza 
Masoumian. Hydrocarbon degradation by thermophilic Nocardiaotitidiscaviarum strain TSH1: physiological aspects. 2007. Journal of Basic Microbiology. 47: 534539.

21. Mojtaba Binazadeh, Iftekhar A. Karimi, Zhi Li. Fast biodegradation of long chain $n$-alkanes and crude oil at high concentrations with Rhodococcussp. Moj-3449. 2009. Enzyme and Microbial Technology. 45: 195-202.

22. Pedro A. Isaza, Andrew J. Daugulis. Ultrasonically Enhanced Delivery and Degradation of PAHs in a Polymer-Liquid Partitioning System by a Microbial Consortium. 2009. Biotechnology and Bioengineering, Vol. 104(1).

23. Ibrahim M. Banat, Andrea Franzetti, Isabella Gandolfi, Giuseppina Bestetti, Maria G. Martinotti, Letizia Fracchia, Thomas J. Smyth \& Roger Marchant. Microbial biosurfactants production, applications and future potential. 2010. Appl Microbiol Biotechnol. 87: 427-444.

24. Christoph Gertler, Daniela J. Nather, Simone Cappello, Gunnar Gerdts, Richard S. Quilliam, Michail M. Yakimov\& Peter N. Golyshin. Composition and dynamics of biostimulated indigenous oil-degrading microbial consortia from the Irish, North and Mediterranean Seas: a mesocosm study. 2012. FEMS Microbiol Ecol, 81:520-536.

25. Mittal \& P. Singh. A feasibility study for assessment of in-situ bioremediation potential of a crude oil degrading Pseudomonas consortium. 2009. J. Sci. Res, 2(1): 127137.

26. Zeynab Bayat, Mehdi Hassanshahian \& Majid AskariHesni. Enrichment and isolation of crude oil degrading bacteria from some mussels collected from the Persian Gulf. 2015. Marine Pollution Bulletin, Vol 101(1): 85-91.

27. Huang Leia, XieJingb, Shi Xiaofengc \& Lian Jingyan. Research on the isolation, identification and degradation characteristics of a diesel oil degrading strain. 2013. Advanced Materials Research, Vol. 641642: 206-210.

28. Ke Shi, Jianliang Xue, Xinfeng Xiao, YanluQiao, Yanan Wu \& Yu Gao. Mechanism of degrading petroleum hydrocarbons by compound marine petroleum-degrading bacteria: surface adsorption, cell uptake and biodegradation. 2019. Energy \& Fuels, 33(11): 11373-11379.
29. David G. Cooper \& Beena G. Goldenberg. SurfaceActive Agents from Two Bacilllus Species. 1986. Applied and environmental microbiology, Vol. 53 (2): 224-229.

30. Pattanathu K S M Rahman, Thahira Rahman, P. Lakshmanaperumalsamy \& Ibrahim M Banat. Towards efficient crude oil degradation by a mixed bacterial consortium. 2003. Bioresource Technology, Vol 85(3): 257-61.

31. Neha Sharma, Meeta Lavania, Vipin Kukreti \& Banwari Lal. Instigation of indigenous thermophilic bacterial consortia for enhanced oil recovery from high temperature oil reservoirs. 2020. PLOS ONE| https://doi.org/10.1371/journal.pone.0229889.

32. Rahman K S M, Rahman T J, Lakshmanaperumalsamy $\mathbf{P}$, Marchant $\mathbf{R} \&$ Banat I M. The potential of bacterial isolates for emulsification with a range of hydrocarbons. 2003. ActaBiotechnol. 23(4): 335-345.

33. Krepsky N, Da Silva FS, Fontana LF \& Crapez, MAC. Alternative methodology for isolation of biosurfactant-producing bacteria. 2007. Braz. J. Biol., 67(1): 117-124.

34. Wilfred F M Roling, Michael G Milner, D Martin Jones, Kenneth Lee, Fabien Daniel, Richard J P Swannell \& Ian M Head. Robust hydrocarbon degradation and dynamics of bacterial communities during nutrient- enhanced oil spill bioremediation. 2002. Applied and Environmental microbiology, Vol. 68(11): 5537-5548.

35. M Vinas, M Grifoll, J Sabate \& AM Solanas. Biodegradation of a crude oil by three microbial consortia of different origins and metabolic capabilities. 2002. Journal of Industrial Microbiology \& Biotechnology, 28: 252-260.

36. Emad I Hussein, Fuad A Al-Horani \& Hanan I Malkawi. Bioremediation capabilities of oil-degrading bacterial consortia isolated from oil-contaminated sites at the Gulf of Aqaba (Jordan). 2012. Biotechnology. 11(4): 189-198.

37. Francesca Crisafi, Laura Giuliano, Michail M. Yakimov, Maurizio Azzaro\& Renata Denaro. Isolation and degradation potential of cold-adapted oil/PAH degrading marine bacterial consortium from Kongsfjorden (Arctic region). 2016.RendicontiLincei, Vol 27: 261-270. 